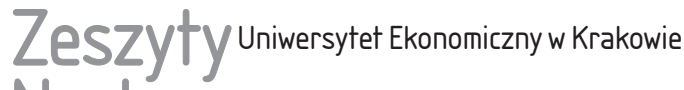 Naukowe
}

\section{Procedury naukowe indukcji zupełnej i niezupełnej w metodologii nauk o zarządzaniu*}

\section{Streszczenie}

Artykuł przedstawia charakterystykę dwóch podstawowych procedur naukowych wykorzystywanych w naukach o zarządzaniu. Procedura indukcji zupełnej oraz procedura indukcji niezupełnej są w nim przedstawiane z perspektywy ogólnej metodologii nauk, filozofii nauki oraz dorobku metodologii nauk o zarządzaniu. Analiza dwóch podstawowych procedur naukowych w sposób szczególny koncentruje się na metodach i technikach oraz dyrektywach metodycznych, odnosząc je do wyróżnionych w procedurach etapów postępowania badawczego.

Słowa kluczowe: procedury naukowe, metodologia, nauki o zarządzaniu, indukcja zupełna, indukcja niezupełna.

Klasyfikacja JEL: M0, M00, M1, M10, M19.

\section{Wprowadzenie}

Metodologia nauk jako dyscyplina naukowa obejmuje bardzo zróżnicowany zbiór metod. W celu ich poznania przyjmuje się różne perspektywy metodologiczne, z których dokonuje się ich analizy. Wszystkie tworzą wielowymiarową

Marek Lisiński, Uniwersytet Ekonomiczny w Krakowie, Katedra Analiz Strategicznych, 31-510 Kraków, ul. Rakowicka 27, e-mail: lisinski@uek.krakow.pl

${ }^{*}$ Niniejszy artykuł powstał w wyniku badań prowadzonych w ramach projektu badawczego pt. „Model doboru metod w procesie rozwiązywania problemów zarządzania” finansowanego ze środków przyznanych przez Narodowe Centrum Nauki (nr decyzji 2014/13/B/HS4/03452). 
przestrzeń klasyfikacyjną metod, z których każda wpisuje się w określone podzbiory takiej przestrzeni.

Metody naukowe mają, jak wszystkie metody, szczególną naturę. Mogą być tylko opisem sposobu działania - są wówczas metodami naukowymi. Mogą także opisywać dyrektywę wskazującą, jak działać - są wtedy metodykami. Mogą wreszcie łączyć w sobie opis działania i dyrektywę wskazującą, jak działać. W takim przypadku mogą przybrać postać procedury naukowej. Charakterystyka procedur naukowych stosowanych w metodologii nauk o zarządzaniu jest właśnie przedmiotem zainteresowania autora.

Celem tego artykułu jest próba charakterystyki dwóch procedur naukowych wykorzystywanych w naukach o zarządzaniu jako dyscyplinie nauk empirycznych. Przedmiotem analizy będzie tu procedura naukowa indukcji zupełnej oraz procedura naukowa indukcji niezupełnej.

Narzędziem badawczym, które posłuży do rozwiązania podjętego tu problemu naukowego, będzie dedukcja. Odniesiona do krytycznego studium literatury, szczególnie z zakresu metodologii ogólnej, filozofii nauki oraz metodologii nauk o zarządzaniu, pozwoli przybliżyć pełne osiągnięcie przyjętego celu badawczego tej pracy ${ }^{1}$.

\section{Pojęcie procedury naukowej}

Podstawową kategorią metodologii nauk jest metoda. Przesądza o jej istocie i jest wyznacznikiem każdej dyscypliny naukowej. W każdej z nich, również w naukach o zarządzaniu, ujawnia w sposób dobitny swój szczególny charakter i zakres.

Aby nie powtarzać sformułowania istoty metody, autor zaakceptuje jej treść wyrażoną we wcześniejszych publikacjach [Lisiński 2011a, s. 17-18]. Dla celów rozwiązania podjętego tu problemu podtrzyma prymat definicji T. Kotarbińskiego ${ }^{2}$ nad innymi określeniami. Przychyli się również do poglądu T. Pszczołowskiego [1978, s. 119], według którego metoda ma dwoistą naturę, co skutkuje dwoma jej znaczeniami. Pierwsze odnosi się do działania - może być tylko sposobem jego opisu, objaśnionym mniej lub bardziej szczegółowo. Jest wówczas, jak się powszechnie przyjmuje, metodą. Drugie dotyczy dyrektywy wskazującej, jak działać. Wówczas jest metodyką. Ta dyrektywa może być

${ }^{1}$ Omówienie tych zagadnień jest kontynuacją rozważań podjętych w opracowaniu [Lisiński 2016b, s. 11-19].

${ }^{2}$ Według T. Kotarbińskiego [1981, s. 524] metoda to sposób systematycznie stosowany, przy czym sposób oznacza tok jakiegoś działania, a więc skład i układ jego stadiów. 
określona na różnym poziomie szczegółowości. Może się zatem charakteryzować różnym poziomem metodyczności.

Takie rozumienie metod skutkuje licznym i zróżnicowanym ich zbiorem. Sprowadzić go można do klasyfikatora metod identyfikowanych w metodologii nauk o zarządzaniu (zob. [Lisiński 2013, s. 132]).

Szczególną kategorią metod są metody naukowe. Aby nie ponawiać raz jeszcze rozważań dotyczących istoty metod naukowych (zob. [Lisiński 2016b, s. 11-12]), dla objaśnienia istoty procedury naukowej autor przyjmie definicję metody naukowej zaproponowaną przez A. Bronka, według którego „metoda naukowa to wysoce wyspecjalizowane narzędzie opisu, wyjaśniania i rozumienia świata, za pomocą którego naukowcy szukają odpowiedzi na postawione pytania oraz budują niearbitralny, wiarygodny i spójny obraz świata" [Bronk 2011, s. 43].

Metody naukowe, podobnie jak wszystkie metody, mogą być opisane w sposób mniej lub bardziej szczegółowy. Mogą również, co także zauważono wcześniej, charakteryzować się różnym stopniem metodyczności. Gdy są tylko opisem sposobu działania, są metodami naukowymi lub technikami naukowymi, gdy zaś wskazują dyrektywę wyznaczająca tok działania, są metodykami naukowymi ogólnymi bądź szczegółowymi. Mogą również łączyć w sobie opis działania i dyrektywę wskazującą, jak działać. W takim przypadku przybierają postać zasady naukowej lub procedury naukowej.

Jedną z metod naukowych, która odpowiada poziomowi o największym poziomie uszczegółowienia, jak już zauważono, jest procedura naukowa. Przy jej definiowaniu autor zwróci uwagę na trzy jej aspekty: przedmiotowy, funkcjonalny i instrumentalny (por. [Stabryła 1986, s. 130]).

Aspekt przedmiotowy procedury naukowej nawiązuje do charakteru problemu jako obiektu, rzeczy, który jest rozwiązywany. Drugi aspekt, funkcjonalny, jest syntezą poszczególnych działań ujętych w ich sekwencję, określającą sposób rozwiązania problemu naukowego. Trzeci aspekt - instrumentalny - określa stopień metodyczności procedury naukowej, przypisując poszczególnym działaniom zestaw wytycznych i wskazań, jak owe działania realizować. Wskazując trzy aspekty procedury naukowej, należy pamiętać, że wyodrębniono je tylko dla pełniejszego uwypuklenia jej istoty. Są bowiem skutkiem zabiegu metodologicznego, świadomie przyjętego dla rozwiązania tego cząstkowego problemu naukowego. W rzeczywistości zespalają się w jedną całość, którą jest procedura naukowa.

Przez procedurę naukową autor będzie tu rozumiał, identyfikując jej aspekt przedmiotowy, sposób objaśniania i rozumienia świata, odkrywania prawdy, odróżniania jej od fałszu i unikania błędu, charakteryzujący się wysokimi standardami wiarygodności, dający spójny obraz badanej rzeczywistości i pozwalający w sposób sprawny rozwiązywać problemy, które stawia świat i życie. 
Rozwiązywanie takich problemów jest jej aspektem funkcjonalnym. Sprowadza się do realizacji szeregu ujętych w sekwencję działań. Działania te są wykonywane i w tym wyraża się aspekt instrumentalny procedury naukowej, przy wykorzystaniu zbioru dyrektyw (zasad, zaleceń, wskazań), które precyzują, jak te działania mają być wykonane. Procedura naukowa jest zatem zestawieniem według chronologicznej kolejności wszystkich świadomych i celowych zachowań podmiotów, czyli ich działań oraz przepisów, wytycznych i reguł, określających ich wykorzystanie w celu rozwiązania problemu naukowego. Tworzy ją nie tylko dokładny opis kolejnych działań, ale również możliwie precyzyjnie wyrażone objaśnienie, jak owe działania mają być wykonane.

Charakter procedury naukowej jako metody naukowej na innym poziomie szczegółowości opisu (zob. [Lisiński 2013, s. 132]) skutkuje określeniem jej miejsca w podstawowych rodzajach typologii metodologii nauk.

Akceptując rozważania związane z zakresem wykorzystania metod naukowych, w szczególności przyjmując jako jedną z perspektyw opisu metod model uzasadniania twierdzeń i budowania teorii naukowych (zob. [Lisiński 2014, s. 137]), co skutkuje ich odniesieniem do nauk empirycznych, autor przyjmie, że procedury naukowe mogą być z powodzeniem wykorzystywane w metodologii nauk o zarządzaniu. Ten wątek rozważań zostanie podjęty w dalszej części pracy.

Istotna dla rozwiązania podjętego tu problemu będzie typologia procedur naukowych. Temu cząstkowemu problemowi poświęcony jest kolejny punkt artykułu.

\section{Typologia procedur naukowych}

W literaturze dotyczącej metodologii ogólnej nie identyfikuje się typologii procedur naukowych. Podobny wniosek można wyprowadzić, studiując literaturę związaną z metodologią nauk o zarządzaniu [Apanowicz 2002, Bronk 2006, Kamiński 1992, Nowak 2012, Niemczyk 2011, Sułkowski 2011, 2012, Witczak 2012, 2014].

Podejmując $\mathrm{w}$ tej części pracy próbę zaproponowania typologii procedur naukowych, w nawiązaniu do przyjętych wcześniej rozstrzygnięć oraz przy założeniu, że procedura naukowa odpowiada metodzie naukowej na najwyższym poziomie uszczegółowienia, autor wykorzysta do rozwiązania tego cząstkowego problemu badawczego swoje poprzednie rozważania dotyczące typologii metod naukowych [Lisiński 2016b, s. 12-13].

Aby nie powtarzać całej analizy dotyczącej tego problemu, tu autor stwierdzi tylko, że to model uzasadniania twierdzeń i budowania teorii naukowych jako kryterium podziału metodologii jako nauki o metodach skutkuje wyróżnie- 
niem metodologii nauk empirycznych, przesądza o takim a nie innym podziale procedur naukowych.

Autor przyjmie, że w naukach o zarządzaniu, jako dyscyplinie naukowej przynależnej do nauk empirycznych, można wskazać cztery procedury naukowe:

1) indukcji zupełnej,

2) indukcji niezupełnej,

3) hipotetyczno-dedukcyjną,

4) dedukcji.

W tym artykule przedstawiona zostanie charakterystyka pierwszych dwóch. Decyzja o wyborze procedur indukcji zupełnej i niezupełnej w celu ich charakterystyki ma powody merytoryczne. Wynikają one z dwóch stanowisk w metodologii nauk, które przyjmuje się w obu procedurach naukowych. Są nimi indukcjonizm oraz weryfikacjonizm. Ich analiza poprzedzona zostanie jednak ogólną uwagą, istotną dla objaśnienia charakteryzowanych tu procedur indukcji. Opisu obu stanowisk metodologicznych autor dokona w kontekście dwóch podstawowych obszarów odniesienia.

Pierwszy tworzą fakty dotyczące zjawisk czy procesów świata rzeczywistego, materialnego związane z działalnością praktyczną. To one są bazą każdej nauki empirycznej, tworzą jej fundament, gdyż to od nich rozpoczynamy uprawianie nauki i za ich pomocą sprawdzamy jej wyniki. To w tej sferze przeprowadza się obserwacje, identyfikuje się sytuację obserwacyjną, dokonuje się indukcyjnego uogólnienia faktów i tutaj potwierdza się wartość teorii poprzez weryfikację lub konfirmację hipotez.

Na drugi obszar odniesienia składają się konstrukcje teoretyczno-metodologiczne nauk o zarządzaniu. Jest on swoistym systemem praw i jest atrybutem tej dyscypliny naukowej. Obejmuje sądy przypadkowo ogólne, egzystencjalne, oraz sądy ściśle ogólne, czyli prawa. Te pierwsze dominujące, choć empirycznie poddane weryfikacji czy konfirmacji, nie mogą być definitywnie potwierdzone, nie są zatem prawami. „Skoro bowiem zasięg prawa jest nieskończony, niemożliwe jest jego przebadanie w żadnym skończonym czasie. Dlatego też we współczesnej metodologii nauki mówi się nie o weryfikacji (całkowitej), lecz o konfirmacji (częściowej) praw" [Krajewski 1982, s. 46]. Sądy takie z czasem mogą w pewnym stopniu pełnić funkcje praw. Sądy ściśle ogólne są prawami nauki, jeśli przynajmniej w przybliżeniu są prawdziwe [Krajewski 1982, s. 43].

Te dwa obszary stanowią spójne i nierozłączne sfery, w których działa podmiot prowadzący badania naukowe i w których wykorzystuje do rozwiązywania problemów zarządzania procedury naukowe.

W pierwszym obszarze odniesienia, gdzie podstawowe znaczenie mają zjawiska i procesy dotyczące działalności praktycznej, rodzą się reguły wykorzystania indukcjonizmu i weryfikacjonizmu w procedurach naukowych indukcji 
zupełnej i niezupełnej. Zjawiska te i procesy stają się bowiem podstawą określenia problemu naukowego i dalej jego rozwiązania odpowiednio do określonego w procedurach toku postępowania naukowego.

Nauki empiryczne opierają się na pewnych zmysłowo dających się zaobserwować zdarzeniach, nazywanych zdaniami obserwacyjnymi [Bocheński 1988, s. 69]. Tworzą one bazę obserwacyjną. Trzeba jednak zauważyć, że nie istnieje „czysta obserwacja”. Obserwacja na gruncie nauki jest uteoretyzowana ${ }^{3}$. Oznacza to, że podmiot prowadzący badania nie jest tym, kto biernie rejestruje wyniki obserwacji. Jego percepcja zależy również od poznawczego tła, które dookreśla strukturę percepcji [Hajduk 2012b, s. 159]. To tzw. zjawisko uteoretyzowania obserwacji i sytuacji obserwacyjnej, co uznać należy za istotną słabość indukcjonizmu ${ }^{4}$.

Według indukcjonizmu do ustalania nowych twierdzeń naukowych, jak również do ich sprawdzania w naukach empirycznych dochodzi się na drodze indukcyjnego uogólniania faktów [Such i Szcześniak 1999, s. 17-18].

Indukcjonizm przyjmuje, „,...) iż podstawową metodą postępowania badawczego nauk empirycznych, prowadzącą do uzyskania najistotniejszych dla tych nauk tzw. syntetycznych (empirycznych) twierdzeń ogólnych, jest indukcja enumeracyjna, czyli indukcja przez wyliczanie" [Kmita 1987, s. 226]. Należy doprecyzować, że charakteryzowane tu procedury indukcji zupełnej i indukcji niezupełnej należą do indukcji enumeracyjnej.

Proces indukcyjnego uogólniania faktów obejmuje dwie grupy działań [Such i Szcześniak 1999, s. 18-19]. Pierwsza polega na przejściu od „szczegółów do ogółu", to znaczy od jednostkowych zjawisk czy procesów empirycznych należących do określonej klasy obiektów do twierdzeń ogólnych obejmujących całe klasy obiektów. Jest więc procesem uogólniania, przejścia od jednostkowych faktów zbadanych do twierdzeń ogólnych niezbadanych. Twierdzenia te jako przesłanki są w toku kolejnych działań indukcyjnego uogólniania faktów podstawą wnioskowania indukcyjnego. Warto przypomnieć tylko, że owe uogólnienia - przesłanki, jako rezultat zjawiska uteoretyzowania obserwacji i sytuacji

3 Ten problem pierwszy podniósł N.R. Hanson [1958, s. 19; 1969, s. 113] inspirowany myślą P. Duhema, zgodnie z którą „,dane obserwacyjne nie są niezależne od teoretycznego tła, zależą zaś istotnie od sposobu rozumienia odnośnej teorii naukowej” (cyt. za: [Hajduk 2012a, s. 157]).

${ }^{4} \mathrm{Na}$ to zjawisko zwraca uwagę między innymi A. Grobler, który stwierdza, że ,teorie uznawane przez obserwatora determinują jego reakcję na otoczenie”, dodając dalej, że „nie tylko obserwacja jest uteoretyzowana, lecz także identyfikacja sytuacji obserwacyjnej jest uteoretyzowana - decyzja, co obserwować - również w sensie dosłownym - także wynika z obserwowanych teorii i założeń”. Rozwijając ten wątek, zauważa, że „,nie sposób niczego zaobserwować bez wcześniejszych oczekiwań ukształtowanych przez posiadane przez nas teorie" oraz dalej że „treść obserwacji zależy od licznych, mniej lub bardziej wyrafinowanych założeń” [Grobler 2008, s. 90-91 i 70-71]. 
obserwacyjnej, nie są czystymi obserwacjami. Zawierają nową treść - „element teoretyczny", jako rezultat wiedzy towarzyszącej podmiotowi realizującemu procedurę naukową.

Druga grupa działań tworzących proces indukcyjnego uogólniania faktów sprowadza się do przejścia „od faktów znanych i zbadanych do faktów nieznanych i niezbadanych". Polega na odniesieniu tego, co wiemy, ze względu na interesujący nas aspekt o faktach nam znanych określonej klasy na fakty nieznane, należące jednak do tej samej klasy. Proces wynikania przebiega zatem od przesłanek do wniosków.

Projekcja, czyli rzutowanie wyników obserwacji na przypadki dotąd niezaobserwowane [Grobler 2008, s. 58], jest realizowana z wykorzystaniem wnioskowania $^{5}$, które jest wnioskowaniem indukcyjnym ${ }^{6}$. Ma ono charakter uogólniający i uprawdopodobniający, w którym wniosek jest zdaniem stwierdzającym ogólną prawidłowość, a przesłanki - niektóre jego przypadki. W tego typu wnioskowaniu wniosek nie wynika logicznie z przesłanek. Proces wnioskowania indukcyjnego jest zatem odwrotny od kierunku wynikania. Znaczy to, że przesłankami rozumowania są następstwa, a wnioskiem racja [Krajewski 1982, s. 95]. O takim wnioskowaniu mówimy, że nie gwarantuje prawdziwości wniosku, lecz jedynie go uprawdopodobnia.

Indukcyjny sposób wnioskowania i identyfikowane w tym procesie tzw. zjawisko uteoretyzowania obserwacji i sytuacji obserwacyjnej należą do wnioskowań zawodnych. Są to takie wnioskowania, w których prawdziwość przesłanek nie przesądza o prawdziwości wniosku. Wśród wnioskowań zawodnych wyróżnić możemy wnioskowania uprawdopodobniające ${ }^{7}$, nazywane także wnioskowaniami subiektywnie niepewnymi ${ }^{8}$.

5 Przez wnioskowanie będziemy rozumieli „(...) proces myślowy, w którym na podstawie mniej lub bardziej stanowczego uznawania przesłanek dochodzimy do uznania wniosku, którego bądź dotychczas nie uznawaliśmy wcale, bądź uznawaliśmy mniej stanowczo; przy czym stopień stanowczości uznania wniosku nie przewyższa stopnia uznania przesłanek" [Ajdukiewicz 1975, s. 106]. Mając na uwadze subiektywny punkt widzenia, można podzielić wnioskowanie na następujące: takie, w którym stopień pewności, z jakim uznajemy wniosek, jest równy stopniowi, z jakim uznaliśmy przesłanki - taki rodzaj rozumowania nazywa się wnioskowaniem subiektywnym pewnym; oraz takie, w którym stopień pewności, z jakim uznajemy wniosek, jest mniejszy od stopnia, z jakim uznaliśmy przesłanki - to wnioskowanie subiektywnie niepewne. Wnioskowania pierwszego i drugiego rodzaju mogą być konkluzywne tylko jako subiektywnie niepewne [Ajdukiewicz 1975, s. 106 i 177-178].

${ }^{6}$ A. Grobler nazywa je rozumowaniem indukcyjnym [Grobler 2008, s. 58].

7 Wnioskowanie uprawdopodobniające to takie, w którym wychodząc od prawdziwych przesłanek, możemy dojść do fałszywego wniosku [Ziembiński 2009, s. 150].

8 Wnioskowanie subiektywnie niepewne to taki rodzaj wnioskowania, w którym stopień pewności, z jakim uznajemy wniosek, jest mniejszy od stopnia, z jakim uznaliśmy przesłanki. 
W procesie wnioskowania można popełnić błędy. Mogą one wynikać z samych przesłanek (błąd materialny) lub z samego procesu wnioskowania (błąd formalny) [Ziembiński 2009, s. 184-187]. We wnioskowaniu indukcyjnym nie można sformułować zarzutu, że popełnia ono błąd formalny. Z założenia wnioskowanie to nie przebiega bowiem według reguł jakiegoś prawa logicznego. Można natomiast popełnić w nim błąd materialny [Ziembiński 2009, s. 184]. Jest on wynikiem zjawiska uteoretyzowania obserwacji i sytuacji obserwacyjnej (wymaga się, aby przesłankom przypisać cechę całkowicie pewnego uznania) lub przemilczenia albo pominięcia którejś z nich w procesie wnioskowania. Może również być skutkiem wiedzy posiadanej przez podmiot prowadzący badania naukowe.

Wnioski wynikające z tak prowadzonego wnioskowania mogą być konkluzywne tylko jako subiektywnie niepewne. Takie wnioski i wynikające z nich, $\mathrm{z}$ uwagi na dominujący w naukach o zarządzaniu proces indukcyjnego uogólniania faktów, sądy przypadkowo ogólne, egzystencjalne są podstawowymi składnikami tej dyscypliny naukowej.

Reasumując ten wątek, można przyjąć, że wnioskowanie subiektywnie niepewne jest w świetle wiedzy podmiotu konkluzywne, „jeżeli stopień pewności, z jakim uznaje się w nim wniosek na podstawie całkowicie pewnego uznania przesłanek, nie przekracza prawdopodobieństwa logicznego wniosku9 ${ }^{9}$, ze względu na przesłanki i posiadaną wiedzę" [Ajdukiewicz 1975, s. 119].

Weryfikacjonizm to drugie stanowisko metodologiczne, które stanowi podstawę procedur indukcji zupełnej i niezupełnej. Nawiązując do dorobku filozofów Koła Wiedeńskiego ${ }^{10}$, zakłada „dążność do maksymalnego potwierdzania

To wnioskowanie może być konkluzywne tylko jako subiektywnie niepewne [Ajdukiewicz 1975, s. 106].

9 Prawdopodobieństwo logiczne jest zrelatywizowane do wiedzy statystycznej i tym samym pozbawione jest arbitralności (zob. [Mortimerowa 1987, s. 222 i 223]). Prawdopodobieństwo we wnioskowaniu konkluzywnym jako subiektywnie niepewnym to „(...) stopień pewności, z jakim mamy prawo zdanie to uznawać" [Ajdukiewicz 1975, s. 119].

10 Pozytywizm jako jeden, obok empiryzmu i fizykalizmu, ze składników teorii filozofii Koła Wiedeńskiego, formułując trzy kategorie twierdzeń, uznawał, że „twierdzenie ma sens, tylko jeśli może być sprawdzone, jeśli możliwa jest jego weryfikacja. A jeśli nie jest, to twierdzenia nie można uważać nawet za fałszywe, po prostu nie ma sensu" [Tatarkiewicz 2005, s. 388]. Wynika stąd, że sensem twierdzenia nie jest jego wartość logiczna, ale sposób, w jaki można na podstawie doświadczeń dowieść jego prawdziwości. Sensem twierdzenia jest zatem metoda jego weryfikacji. J.M. Bocheński, objaśniając ten problem, stwierdza, że opierający się na pozytywistycznej filozofii metodologowie Koła Wiedeńskiego, jak również zwolennicy szkoły empiryczno-logicznej rozciągnęli postulat weryfikalności zdań na całość poznania, łącząc go z metodą, która pozwala nam stwierdzić, czy pewne zdanie jest prawdziwe czy fałszywe (zob. [Bocheński 1988, s. 40]). Dalej zauważa, że w rozwoju nauk przyrodniczych weryfikowalność stała się niezwykle ważna dla metodologii. Znajduje to wyraz w dwóch fundamentalnych regułach nazwanych zasadami 
i uprawdopodobniania istniejących i nowo formułowanych teorii" [Such i Szcześniak 1999, s. 20]. Weryfikacjonizm przyjmuje za cel postępowania naukowego wykazywanie prawdziwości już funkcjonujących, ale także dopiero tworzonych praw.

Istota weryfikacjonizmu polega więc na tym, że nie podważa się wartości logicznej określonego wniosku, nie dyskredytuje się jego znaczenia, ale uznaje się, że to sposób, w jaki dowodzi się jego prawdziwości, przesądza o jego sensie. Sens twierdzenia wyznacza metoda jego weryfikacji. Twierdzenie ma sens tylko, jak stwierdza W. Tatarkiewicz, jeśli może być sprawdzone.

Weryfikacjonizm stanowi istotne dopełnienie indukcjonizmu. Ma na celu ograniczenie skutków wnioskowania subiektywnie niepewnego, czy - jak to nazywa Z. Ziembiński - wnioskowania uprawdopodobniającego. Ma podnieść stopień prawdopodobieństwa we wnioskowaniu konkluzywnym.

Raz jeszcze należy przypomnieć, że wszystkie negatywne skutki indukcjonizmu mają swe źródło w zjawisku uteoretyzowania obserwacji i sytuacji obserwacyjnej. To z powodu niemożności dokonania czystych obserwacji, a także innych nieprawidłowości procesu indukcyjnego uogólniania faktów powstają błędy materialne. Formułowane w taki sposób wnioski mogą być konkluzywne tylko jako subiektywnie niepewne.

Wskazane informacje upoważniają do konstatacji, że proces weryfikacji jest całą sekwencją działań, które mają na celu maksymalne potwierdzanie i uprawdopodobnianie formułowanych wniosków. Nie bez powodu stanowisko intuicjonisty sprowadza się niejednokrotnie do postawy weryfikacjonisty [Such i Szcześniak 1999, s. 27], a cały proces budowania teorii zmierza do wykazywania wysokiego stopnia jej prawdopodobieństwa lub nawet jej prawdziwości.

Procedura indukcji zupełnej i procedura indukcji niezupełnej, oparte na dwóch scharakteryzowanych tu stanowiskach w metodologii nauk, są instrumentami prowadzenia badań naukowych w naukach o zarządzaniu. Ich zastosowanie jest jednoznacznie związane z zakresem prowadzonego badania.

Jeśli wiadomo, że nie ma innych zjawisk czy procesów oprócz tych, które zostały wyznaczone jako przedmiot badania, a także i to, że możliwe jest objęcie postępowaniem badawczym całej ich populacji, to celowe i uzasadnione jest zastosowanie procedury indukcji zupełnej. Indukcja zupełna to „,...) wyprowadzanie ogólnej prawidłowości na podstawie stwierdzenia wszystkich jej poszczególnych przypadków" [Krajewski 1982, s. 95]. Takie sytuacje są możliwe tylko wówczas, gdy zbiór zjawisk czy procesów jest skończony, a jednocześnie

weryfikalności. Brzmią one: „1. Zdanie jest wtedy sensowne semantycznie, gdy można pokazać metodę, dzięki której jest ono weryfikowalne. 2. Wyrażenie nie będące zdaniem jest wtedy sensowne semantycznie, gdy można go używać jako części semantycznie sensownego, a więc weryfikowalnego zdania" [Bocheński 1988, s. 40]. 
nieliczny. Możliwe jest zatem wnioskowanie o wszystkich obiektach danej klasy. Wnioskowanie przez indukcję zupełną jest wnioskowaniem niezawodnym [Ziembiński 2009, s. 184]. Przesłanki w takim procesie wnioskowania wynikają logicznie z wniosku, ale o dedukcyjności wnioskowania stanowi to, że zarazem wniosek wynika w nim logicznie z przesłanek ${ }^{11}$.

$\mathrm{Z}$ uwagi na powszechne $\mathrm{w}$ indukcji zjawisko uteoretyzowania obserwacji i sytuacji obserwacyjnej, które skutkuje identyfikowanymi błędami materialnymi leżącymi w samych przesłankach, wnioskowanie takie nie gwarantuje prawdziwości wniosku, lecz jedynie go uprawdopodobnia.

Inna jest sytuacja, gdy kryteria wyboru problemu naukowego nie dają podstawy do objęcia nim wszystkich zjawisk czy procesów składających się na ich klasę. Możemy wówczas przebadać tylko nieliczny podzbiór zjawisk czy procesów danej klasy. Jeśli badając tylko pewne zjawiska czy procesy danej klasy, stwierdzimy, że każde z nich ma pewną cechę, to wnioskujemy stąd, że cechę tę mają wszystkie zjawiska czy procesy danej klasy. Takie przypadki w naukach o zarządzaniu są niemal powszechne. Wówczas wykorzystujemy procedurę indukcji niezupełnej.

Autor syntetycznie omówi kolejno procedurę naukową indukcji zupełnej oraz procedurę naukową indukcji niezupełnej. Ich charakterystyka zostanie dokonana, jak przyjęto we wstępie tej pracy, w kontekście ogólnej metodologii nauk oraz filozofii nauki z uwzględnieniem specyfiki nauk o zarządzaniu.

\section{Procedura naukowa indukcji zupełnej}

Procedura indukcji zupełnej, jak wcześniej zauważono, oparta jest na indukcjonizmie i weryfikacjonizmie. Pozwala zatem na formułowanie wniosków, które mogą być konkluzywne tylko jako subiektywnie niepewne.

Procedurę indukcji zupełnej uwzględniającą charakter nauk o zarządzaniu przedstawia tabela 1 . Kluczowe jej składniki zostaną teraz omówione w syntetyczny sposób. Szczególna uwaga zostanie zwrócona na metody i techniki oraz dyrektywy metodyczne proponowane do wykorzystania w toku realizacji jej poszczególnych etapów.

Procedura indukcji zupełnej obejmuje trzy podstawowe fazy. Pierwszą można sprowadzić do trzech następujących po sobie etapów. Są to określenie problemu naukowego, identyfikacja faktów oraz analiza faktów.

11 Wnioskowanie indukcyjne w indukcji zupełnej, przy odpowiednim rozszerzeniu pojmowania wynikania logicznego, jest wnioskowaniem dedukcyjnym [Ziembiński 2009, s. 140]. Można więc zauważyć, że takie wnioskowanie indukcyjne, przy spełnieniu pewnych warunków, jest wnioskowaniem dedukcyjnym i może eliminować popełnienie błędu formalnego. 


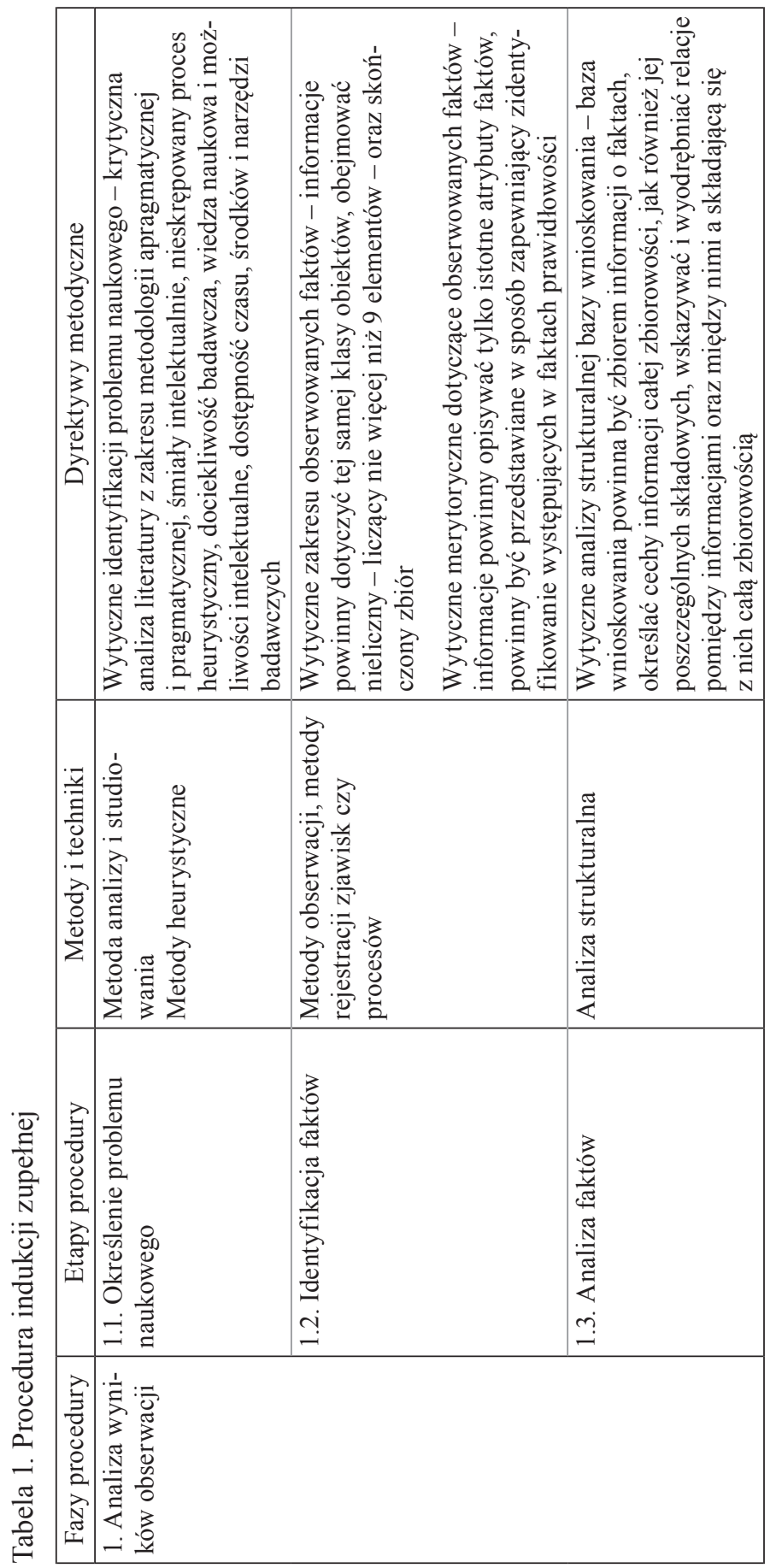




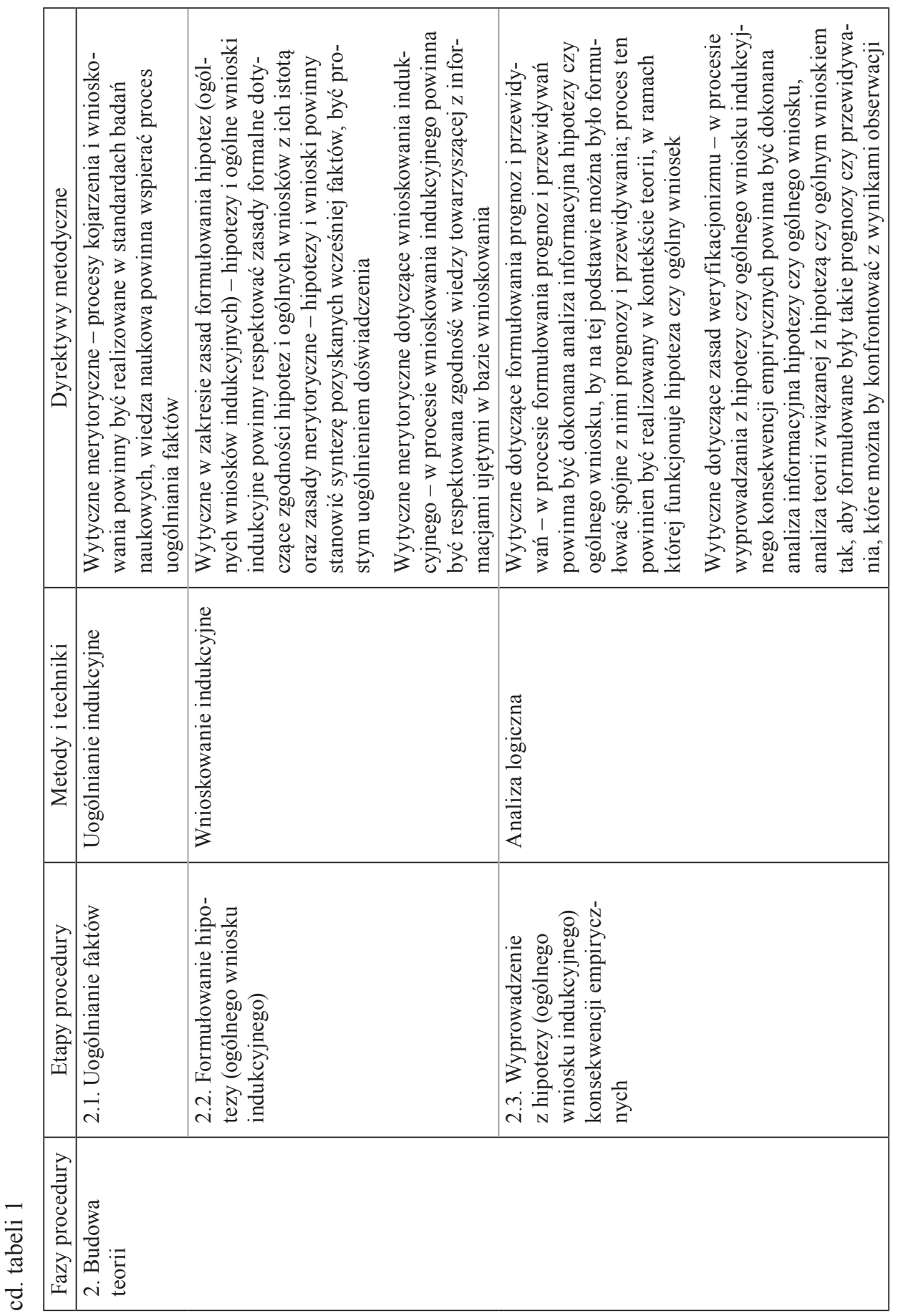




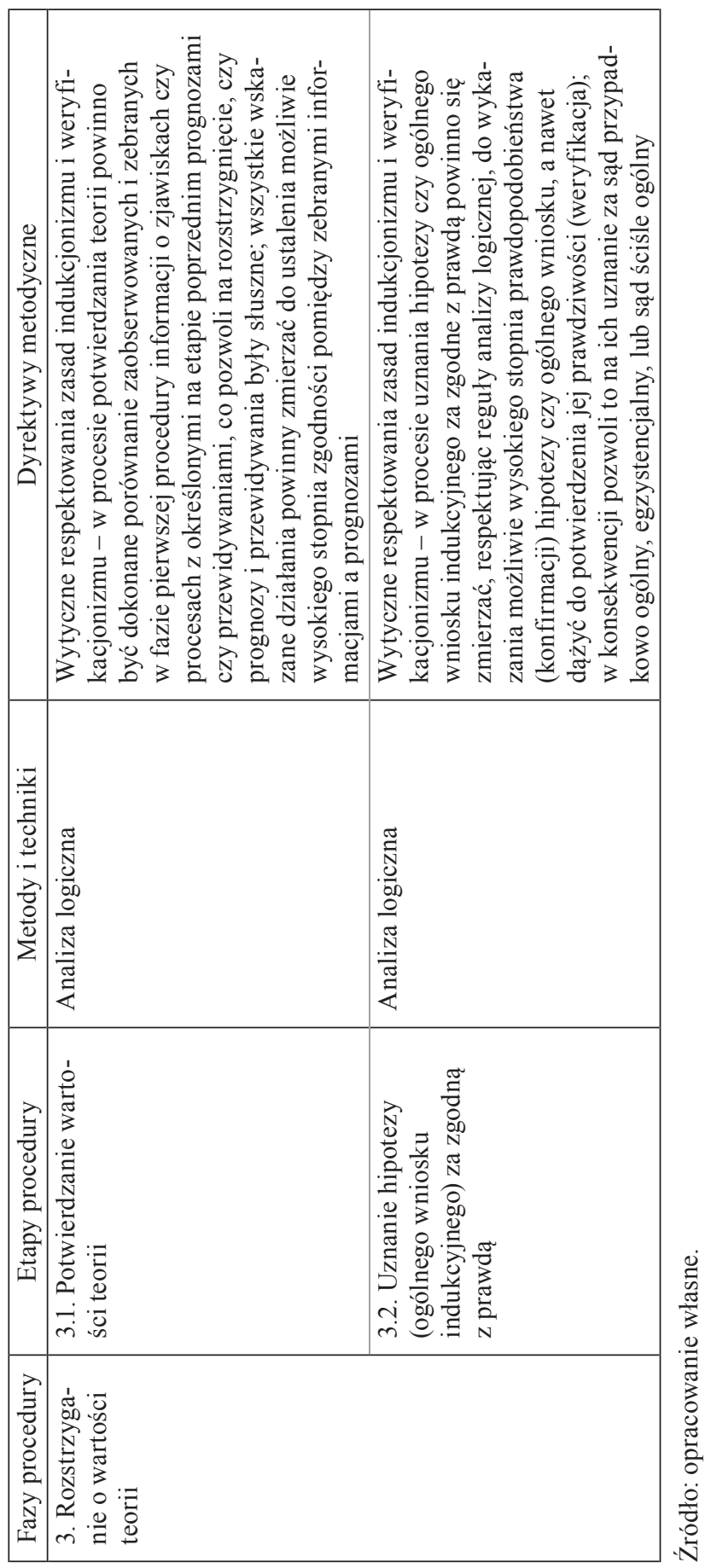


Określenie problemu naukowego jest odzwierciedleniem braków w teorii nauk o zarządzaniu. Jego źródłem może być ustalenie nowych twierdzeń naukowych, tez, aksjomatów czy uogólnień. Może być nim również brak odpowiedzi naukowych na pytania wynikające $z$ aktualnego stanu wiedzy dotyczącej teorii tej dyscypliny naukowej lub identyfikowane błędy w takich odpowiedziach. Respektowanie metodycznych wytycznych identyfikacji problemu naukowego ułatwi jego określenie, pozwoli również na ustalenie celu i granic pracy naukowej.

Identyfikacja faktów polega na zebraniu i zarejestrowaniu zjawisk czy procesów jednostkowych, które staną się podstawą późniejszej ich analizy. Przy wykonywaniu działań tego etapu należy wykorzystać znane powszechnie metody obserwacji i rejestracji faktów, a realizowane czynności podporządkowywać wytycznym określającym charakter i liczebność identyfikowanej populacji zjawisk czy procesów ${ }^{12}$.

Analiza faktów, jako trzeci etap fazy pierwszej, zmierza do ułatwiającego proces uogólniania indukcyjnego, ustrukturyzowania informacji tworzących bazę wnioskowania. Informacje te powinny być ujęte zgodnie z wymaganiami analizy strukturalnej [Lisiński 2011b, s. 201]. Dopiero takie zestawienie informacji w bazie wnioskowania może być podstawą realizacji kolejnych etapów procedury.

Faza druga procedury indukcji zupełnej - budowa teorii - konkretyzuje się w trzech etapach. Są to kolejno: uogólnianie faktów, formułowanie hipotezy (ogólnego wniosku indukcyjnego) oraz wyprowadzenie z hipotezy (ogólnego wniosku indukcyjnego) konsekwencji empirycznych. Wszystkie te etapy zespalają w sobie założenia indukcjonizmu oraz weryfikacjonizmu i są zarazem ich konkretyzacją.

Uogólnianie faktów to szczególny proces polegający na przejściu od faktów jednostkowych zbadanych, zestawionych w bazie wnioskowania, do twierdzeń ogólnych, jako ich indukcyjnych uogólnień. Podporządkowany jest on regułom uogólniania indukcyjnego, a w sposób szczególny wytycznym merytorycznym ograniczającym nieprawidłowości indukcyjnego procesu uogólniania faktów.

Formułowanie hipotezy (ogólnego wniosku indukcyjnego) polega na całej sekwencji działań, których celem jest odniesienie faktów znanych i zbadanych, ujętych w bazie wnioskowania, w celu ustalenia faktów nieznanych i niezbadanych, przynależnych jednak do tej samej klasy obiektów. Metodą umożliwiającą rozwiązanie tego cząstkowego zadania naukowego jest wnioskowanie indukcyjne.

12 Dla respektowania wytycznych indukcji zupełnej autor proponuje, aby liczebność populacji faktów nie była zbiorem liczącym więcej niż 9 elementów. Wynika to z liczby Millera - maksymalna liczba informacji, jaką człowiek jest w stanie rozróżnić bezpośrednio, przyjmuje rozrzut wartości w przedziale $7 \pm 2$ (zob. [Miller 1956, s. 81-97]). 
Analitycznie patrząc, proces wynikania przebiega od przesłanek do wniosków. W toku wnioskowania indukcyjnego, który - jak wcześniej zaznaczono przebiega odwrotnie niż proces wynikania, a więc przesłankami rozumowania są następstwa, a wnioskiem racja, formułuje się wniosek indukcyjny. Może on mieć postać - jak sądzi się powszechnie - hipotezy ${ }^{13}$ lub ogólnego wniosku indukcyjnego ${ }^{14}$.

Istota hipotezy w procedurze indukcji zupełnej, a szczególnie jej wykorzystanie w procesie indukcyjnego uogólniania faktów, są typowe dla indukcjonizmu [Such i Szcześniak 1999, s. 18-20]. Skutkuje to przyjęciem jako zasady formułowania twierdzeń jak najmniej ryzykownych i jak najbardziej prawdopodobnych. W hipotezie wyraża się dążność do maksymalnego potwierdzania i uprawdopodobnienia istniejących i nowo formułowanych praw jako składników teorii.

Hipoteza jest tylko instrumentem wspomagającym proces wnioskowania. Przenoszenie części pewności, z jakimi uznaliśmy przesłanki, na hipotezy (ogólne wnioski indukcyjne) powinno dokonywać się w zgodności wiedzy towarzyszącej procesowi wnioskowania indukcyjnego z bazą wnioskowania.

Hipotezie (ogólnemu wnioskowi indukcyjnemu), jako wytworowi procesu wnioskowania subiektywnie niepewnego, można przypisać prawdopodobieństwo. Jest ono adekwatne do określonych wcześniej i istotnych z punktu widzenia rozwiązywanego problemu naukowego faktów oraz przesłanek jako ich uogólnień. Jeśli proces uogólniania respektuje wytyczne metodyczne, a wnioskowanie indukcyjne uwzględnia wymagania merytoryczne i metodologiczne, to hipotezie (ogólnemu wnioskowi indukcyjnemu) można przypisać relatywnie wysoki stopień prawdopodobieństwa we wnioskowaniu konkluzywnym.

W całym procesie formułowania hipotezy (ogólnego wniosku indukcyjnego) pamiętać należy o respektowaniu zasad weryfikacjonizmu, co wyraża się

${ }^{13}$ Hipoteza w procedurze indukcji zupełnej stanowi swoistą syntezę pozyskanych wcześniej, a ujętych w formie bazy wnioskowania, faktów i twierdzeń znanych i zbadanych. Jest prostym uogólnieniem doświadczenia, nie wywołuje zdziwienia, niedowierzania, nie jest także źródłem oporu części społeczności naukowej (zob. [Krajewski 1982, s. 126-128]).

$14 \mathrm{~W}$ pewnym zbiorze problemów naukowych rozwiązywanych z wykorzystaniem procedury indukcji zupełnej konieczne nie jest formułowanie hipotez, lecz poprzestanie na określeniu wniosku indukcyjnego (zob. [Krajewski 1982, s. 126]). Dotyczy to tych przypadków, w których problem naukowy jest bardzo prosty i polega na postawieniu pytań rozstrzygnięcia. Pytania rozstrzygnięcia, które obok pytań dopełnienia wyróżnia się w logice pytań, w języku polskim rozpoczynają się od partykuły „czy”. Te pytania dopuszczają tylko dwie odpowiedzi: „tak” lub „nie”. Pytania dopełnienia rozpoczynają się od innych słów: „kto”, „gdzie”, „kiedy”, „,jak” itp. (zob. [Krajewski 1982, s. 125]). Postawienie pytań rozstrzygnięcia i uzyskanie na nie jednoznacznych odpowiedzi pozwala na ustalenie, czy wszystkie zjawiska czy procesy należące do określonej klasy obiektów mają istotną, interesująca nas cechę. Wówczas należy obserwować tę zbiorowość pod kątem tej cechy. W takich właśnie sytuacjach funkcje hipotezy spełnia ogólny wniosek indukcyjny. 
w takim określeniu hipotezy (ogólnego wniosku indukcyjnego), by potwierdzić fakty zestawione w bazie wnioskowania.

Ostatni etap tej fazy to wyprowadzenie z hipotezy (ogólnego wniosku indukcyjnego) konsekwencji empirycznych. Działania wykonywane w ramach tego etapu sprowadzają się do przeprowadzenia wywodu konsekwencji empirycznych z hipotezy (ogólnego wniosku indukcyjnego). W istocie polega to na dokonaniu analizy informacyjnej hipotezy (ogólnego wniosku indukcyjnego) po to, aby określić, jaką treść empiryczną zawiera. Ów wywód konkretyzuje się w sfomułowaniu prognoz czy przewidywań, odpowiednio do przyjętej hipotezy (ogólnego wniosku indukcyjnego). Proces ten realizowany jest w kontekście teorii, w ramach której funkcjonuje hipoteza (ogólny wniosek indukcyjny). Metodą zapewniającą wykonanie tego cząstkowego zadania jest analiza logiczna. Pozwala na ustalenie tego, co wynika z analizy hipotezy, a jest związane z zaobserwowanymi faktami.

Przedsięwzięciom tym towarzyszą działania wpisujące się weryfikacjonizm, jako drugie stanowisko w metodologii nauk. Ich istotę możena ująć w stwierdzeniu: należy dokonywać takiej analizy informacyjnej hipotezy (wniosku indukcyjnego), takiej analizy teorii, związanej z hipotezą, aby formułować takie prognozy czy przewidywania, które można by konfrontować $\mathrm{z}$ faktami.

Rozstrzyganie o wartości teorii składa się na trzecią fazę procedury indukcji zupełnej. Obejmuje dwa następujące etapy: potwierdzanie wartości teorii oraz uznanie hipotezy (ogólnego wniosku indukcyjnego) za zgodną z prawdą.

Etap pierwszy polega na porównaniu zebranych i zaobserwowanych faktów z określonymi na etapie poprzednim prognozami czy przewidywaniami, a następnie rozstrzygnięciu, czy te antycypacje faktów były słuszne. To porównanie czynione z wykorzystaniem analizy logicznej, ale również podporządkowane regułom weryfikacjonizmu (dążeniu do ustalenia możliwie wysokiego stopnia zgodności pomiędzy faktami a prognozami) zmierza do stwierdzenia, czy procesowi potwierdzania wartości teorii można przypisać atrybut poprawności.

Drugi, końcowy etap tej fazy, ale i całej procedury, to uznanie hipotezy (ogólnego wniosku indukcyjnego) za zgodną z prawdą. Jest to jednocześnie rozstrzyganie o wartości teorii poprzez konfirmację czy weryfikację hipotez (ogólnego wniosku indukcyjnego).

Jak wcześniej zauważono, proces wnioskowania indukcyjnego jest procesem zawodnym. Działania tego etapu zmierzają do wykazania wysokiego stopnia prawdopodobieństwa (konfirmacji) hipotezy czy nawet potwierdzenia jej prawdziwości (weryfikacji). Przypisanie jej wysokiego stopnia prawdopodobieństwa pozwoli uznać hipotezę za sąd przypadkowo ogólny, egzystencjalny. Uznanie prawdziwości hipotezy daje podstawę do stwierdzenia, że jest sądem 
ściśle ogólnym, czyli prawem. Staje się wówczas składnikiem teorii, która jest systemem praw [Krajewski 1982, s. 47].

\section{Procedura naukowa indukcji niezupelnej}

Procedura indukcji niezupełnej, co wcześniej już zasygnalizowano, oparta jest na indukcjonizmie i weryfikacjonizmie. Należy tu także dodać, że fazy tej procedury są identyczne jak w przypadku omawianej wcześniej procedury indukcji zupełnej.

Procedurę indukcji niezupełnej przedstawia tabela 2. Omówione zostaną teraz jej podstawowe składniki. W opisie wyeksponowane zostaną te jej aspekty (metody i techniki oraz dyrektywy metodyczne), które są dla niej istotne, a jednocześnie odróżniają ją od omówionej wcześniej indukcji zupełnej.

Faza pierwsza to analiza wyników obserwacji, na która składają się trzy etapy. Są to kolejno: określenie problemu naukowego, identyfikacja faktów i analiza faktów.

Określenie problemu naukowego sprowadza się, podobnie jak w indukcji zupełnej, do identyfikacji wszystkich źródeł, które wskazują na braki w teorii nauk o zarządzaniu. Ustalenie tych zjawisk pozwala na zdefiniowanie problemu naukowego, a w dalszej kolejności na ustalenie jego celu oraz granic pracy naukowej.

Identyfikacja faktów polega na zebraniu i zarejestrowaniu zjawisk czy procesów jednostkowych, które staną się podstawą późniejszej ich analizy. Do realizacji zadań tego etapu należy zastosować powszechnie znane metody obserwacji i rejestracji zjawisk czy procesów. Należy dodać, że prawdopodobieństwo wniosku uzyskanego poprzez wykorzystanie indukcji niezupełnej jest tym większe, w im większym stopniu wypełnione są wytyczne merytoryczne dotyczące obserwowanych faktów [Krajewski 1982, s. 98 i 99].

Analiza faktów kończy pierwszą fazę procedury. Sprowadza się ona do określenia bazy wnioskowania. Jej składnikami są zarejestrowane wcześniej fakty empiryczne. Powinny one zostać ujęte zgodnie z wymaganiami techniki opisu naukowego [Hajduk 2012b, s. 106-107]. Opis taki umożliwia dokładne, jednoznaczne i obiektywne scharakteryzowanie informacji o zarejestrowanych faktach, a także ich zestawienie w taki sposób, by stanowiły najlepszą podstawę do indukcyjnego uogólniania faktów [Hajduk 2012b, s. 106-107].

Faza druga procedury indukcji niezupełnej - budowa teorii - jest realizowana w następujących trzech etapach: uogólnienie faktów, formułowanie hipotez oraz wyprowadzenie z hipotez konsekwencji empirycznych. 


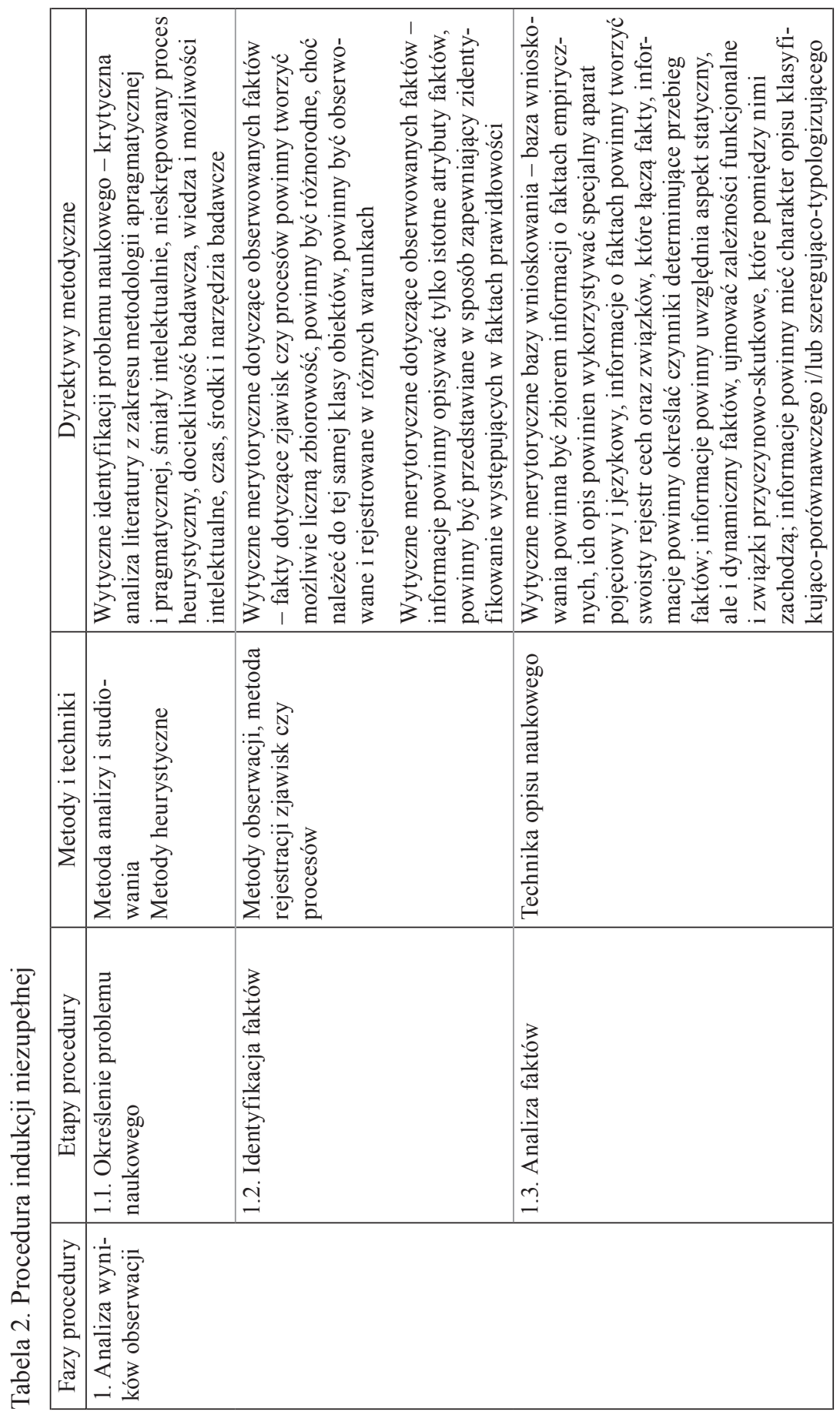




\begin{tabular}{|c|c|c|c|c|}
\hline & 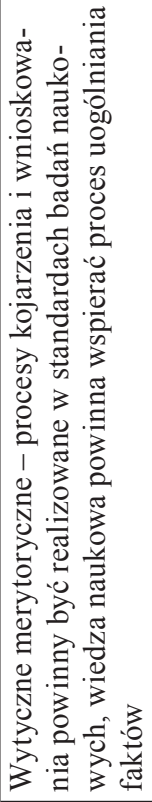 & 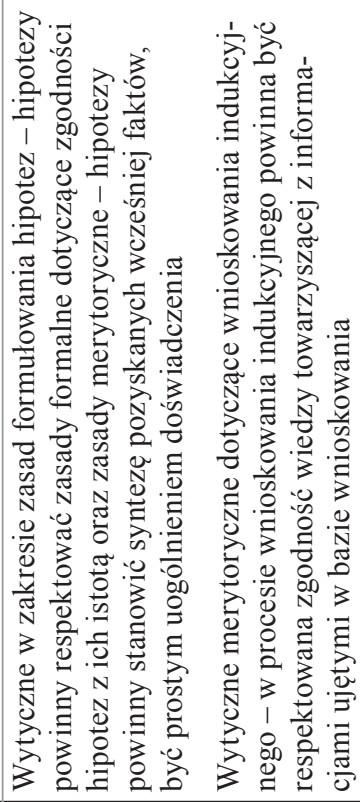 & 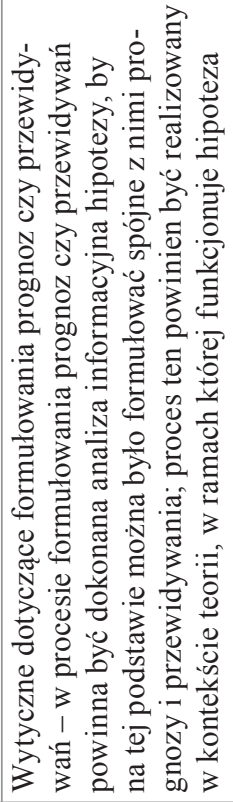 & 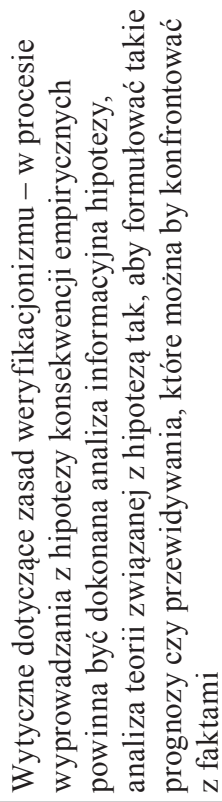 \\
\hline 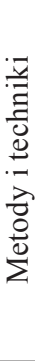 & 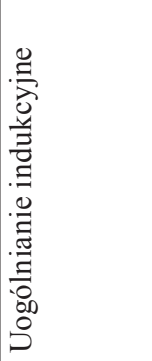 & 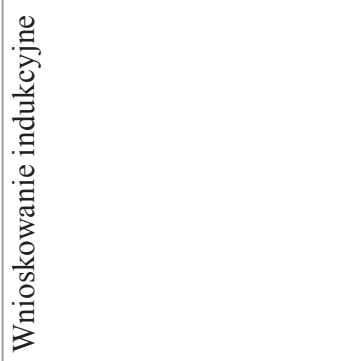 & 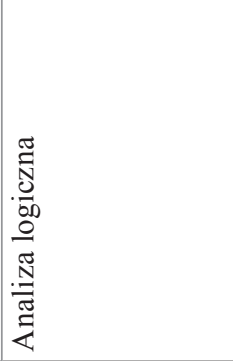 & \\
\hline 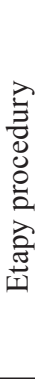 & 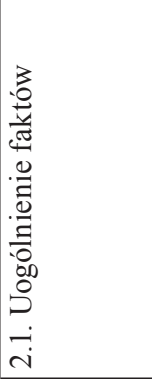 & 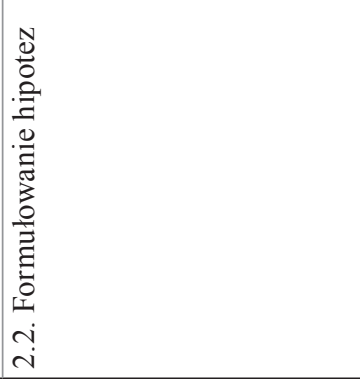 & 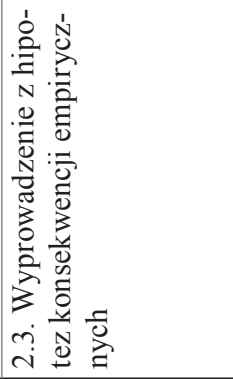 & \\
\hline 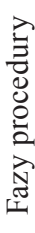 & 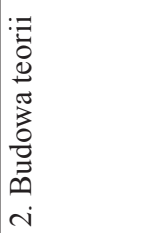 & & & \\
\hline
\end{tabular}




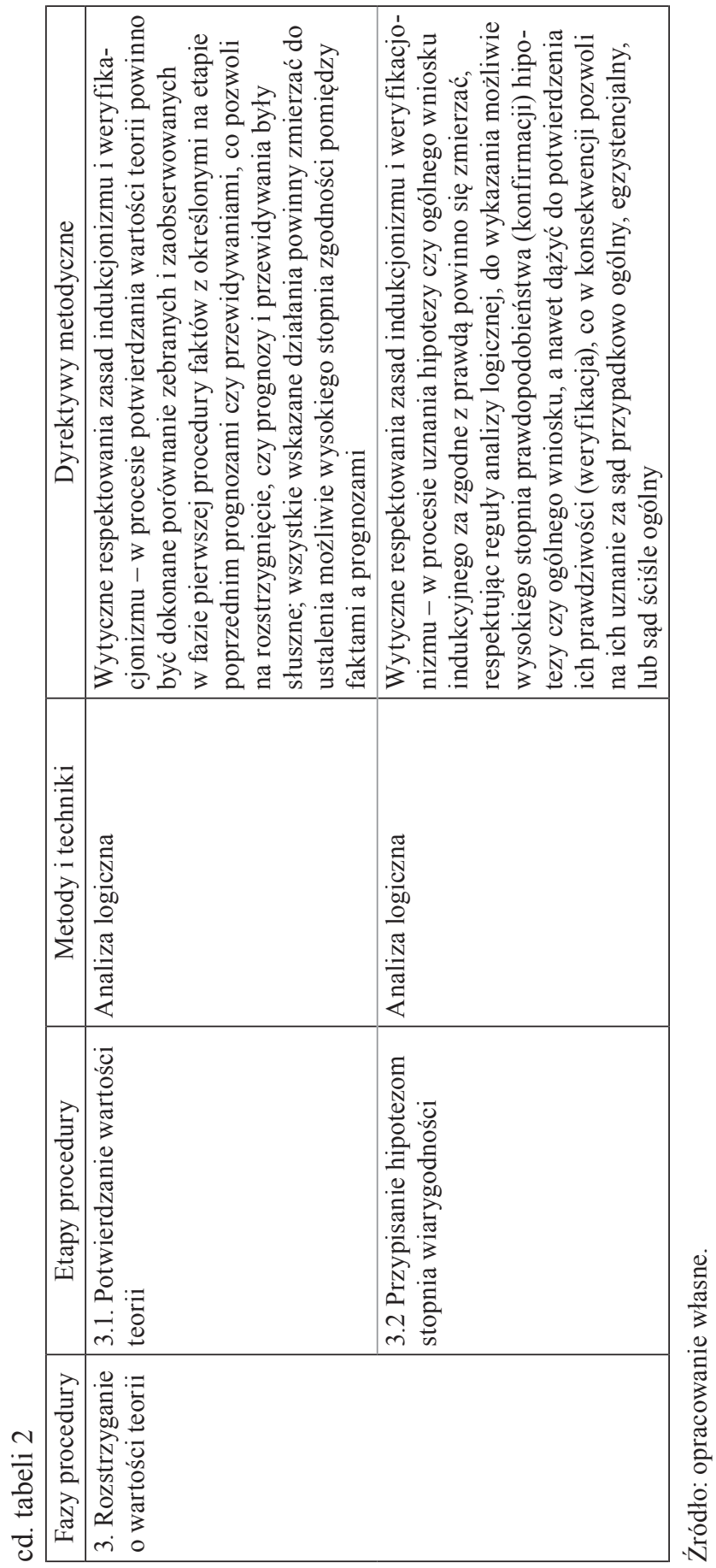


Uogólnienie faktów to sekwencja działań, które w swym merytorycznym i metodologicznym zakresie podobne są do tych opisanych wcześniej przy charakteryzowaniu procedury indukcji zupełnej. Są realizowane według standardów uogólnienia indukcyjnego. Proces ten powinien respektować wymagania merytoryczne ograniczające nieprawidłowości indukcyjnego uogólniania faktów.

Formułowanie hipotez stanowi kolejny etap drugiej fazy. Wykonywane tu działania sprowadzają się do odniesienia tego, co wiemy, ze względu na interesujący nas aspekt o faktach nam znanych określonej klasy na fakty nieznane, należące jednak do tej samej klasy. Narzędziem umożliwiającym ustalenie ogólnych prawidłowości o wszystkich faktach danej klasy jest hipoteza ${ }^{15}$, a metodą pozwalającą na jego skuteczne przeprowadzenie jest wnioskowanie indukcyjne. Proces formułowania hipotez przebiega w podobny sposób jak w procedurze indukcji zupełnej. Przy określaniu hipotez należy respektować wytyczne w zakresie zasad ich formułowania oraz wytyczne merytoryczne dotyczące wnioskowania indukcyjnego.

Należy również pamiętać o wypełnianiu zasad weryfikacjonizmu, co wyraża się w takim określeniu hipotez, aby potwierdzić fakty zestawione w bazie wnioskowania.

Ostatni etap tej fazy to wyprowadzenie z hipotezy konsekwencji empirycznych. Działania wykonywane w ramach tego etapu w swej istocie są identyczne jak w procedurze indukcji zupełnej. Dla wyprowadzenia z hipotezy konsekwencji empirycznych, które konkretyzować się będą w określonych prognozach czy przewidywaniach, wykorzystuje się także analizę logiczną. Jest to antycypacja tego, co wynika $\mathrm{z}$ analizy hipotezy, a jest związane z zaobserwowanymi faktami. $\mathrm{W}$ procesie tym należy wypełniać wytyczne dotyczące formułowania prognoz czy przewidywań, a także respektować zasady weryfikacjonizmu.

Rozstrzyganie o wartości teorii, jako trzecia faza procedury indukcji niezupełnej, kończy cały proces badania naukowego. Obejmuje dwa następujące po sobie etapy: potwierdzania wartości teorii oraz przypisania hipotezom stopnia wiarygodności.

Na pierwszym etapie są wykonywane działania, które mają na celu potwierdzenie wartości teorii. Następuje to poprzez testowanie hipotez, a ściślej sprawdzanie ich konsekwencji empirycznych. Testowanie hipotez następuje poprzez porównanie zebranych i zaobserwowanych faktów z określonymi na etapie poprzednim prognozami czy przewidywaniami, a następnie rozstrzygnięcie, czy te antycypacje faktów były słuszne.

Wykonanie tych działań jest prowadzone z zastosowaniem analizy logicznej oraz przy respektowaniu reguł weryfikacjonizmu. Zmierza do ustalenia możliwie

${ }^{15}$ Hipotezę w procedurze indukcji niezupełnej rozumiemy identycznie jak w procedurze indukcji zupełnej. 
wysokiego stopnia zgodności pomiędzy faktami a prognozami. Umożliwia to potwierdzenie wartości teorii.

Drugi, końcowy etap tej fazy, ale i całej procedury to uznanie hipotezy za zgodną z prawdą. Jest to jednocześnie rozstrzyganie o wartości teorii.

$\mathrm{Na}$ tym etapie procedury, podobnie jak w przypadku indukcji zupełnej, realizowane działania zmierzają do wykazania wysokiego stopnia prawdopodobieństwa, czyli konfirmacji hipotezy, czy nawet potwierdzenia jej weryfikacji, a więc uznania jej prawdziwości. Skutkuje to przyjęciem konstatacji, że hipoteza staje się sądem przypadkowo ogólnym, egzystencjalnym bądź sądem ściśle ogólnym, czyli prawem. W obu przypadkach jest składnikiem teorii.

\section{Uwagi końcowe}

Przedstawiona charakterystyka procedur naukowych stanowi próbę omówienia tych instrumentów badania naukowego do rozwiązywania problemów zarządzania ${ }^{16}$. Procedura naukowa indukcji zupełnej oraz procedura naukowa indukcji niezupełnej zostały przedstawione z perspektywy ogólnej metodologii nauk, filozofii nauki oraz dorobku metodologii nauk o zarządzaniu.

$\mathrm{W}$ artykule autor $\mathrm{w}$ analizie dwóch podstawowych procedur naukowych wykorzystywanych w naukach o zarządzaniu w sposób szczególny koncentruje się na metodach i technikach oraz dyrektywach metodycznych, odnosząc je do wyróżnionych w procedurach etapów postępowania badawczego.

Wszystkie prezentowane tu dokonania powinny wywoływać twórczą krytykę oraz stanowić naukową inspirację do prowadzenia dalszych prac naukowych dotyczących doskonalenia tego instrumentarium metodologicznego oraz jego dalszego wykorzystania w rozwoju metodologii nauk o zarządzaniu.

\section{Literatura}

Ajdukiewicz K. [1975], Logika pragmatyczna, PWN, Warszawa.

Apanowicz J. [2002], Metodologia ogólna, Wydawnictwo Diecezji Pelplińskiej „Bernardinum", Gdynia.

Bocheński J.M. [1988], Współczesne metody myślenia, Wydawnictwo W drodze, Poznań. Bronk A. [2006], Metoda naukowa, „Nauka”, nr 1.

Bronk A. [2011], Pojęcie i rodzaje metody naukowej [w:] Podstawy naukoznawstwa, red.

P. Kawalec, R. Wodzisz, t. 1, Katolicki Uniwersytet Lubelski, Lublin.

Grobler A. [2008], Metodologia nauk, Wydawnictwo Aureus, Kraków.

${ }^{16}$ Kwestie dotyczące pojawiania się nowych problemów zarządzania oraz ich rozwiązywania z perspektywy nauk o zarządzaniu wskazuje m.in. M. Szarucki [2015, s. 362-372]. 
Hajduk Z. [2012a], Metodologiczna charakterystyka relacji między teoria i doświadczeniem, Roczniki Filozoficzne, t. LX, nr 4-2012.

Hajduk Z. [2012b], Ogólna metodologia nauk, wyd. 6 uzup., Katolicki Uniwersytet Lubelski, Lublin.

Hanson N.R. [1958], Patterns of Discovery: An Inquiry into the Conceptual Foundations of Science, Cambridge.

Hanson N.R. [1969], Perception and Discovery: An Introduction to Scientific Inquiry, San Francisco.

Kamiński S. [1992], Nauka i metoda. Pojęcie i klasyfikacja nauk, wyd. 6 popr., Katolicki Uniwersytet Lubelski, Lublin.

Kmita J. [1987], Indukcjonizm i antyindukcjonizm [w:] Filozofia a nauka. Zarys encyklopedyczny, red. Z. Cackowski, J. Kmita, K. Szaniawski, P.J. Smoczyński, Ossolineum, Wrocław.

Kotarbiński T. [1981], Traktat o dobrej robocie, Ossolineum, Warszawa.

Krajewski W. [1982], Prawa nauki. Przegląd zagadnień metodologicznych, Książka i Wiedza, Warszawa.

Lisiński M. [2011a], Analiza metodologii nauk o zarządzaniu [w:] Rozwój koncepcji i metod zarządzania, red. J. Czekaj, M. Lisiński, Fundacja Uniwersytetu Ekonomicznego w Krakowie, Kraków.

Lisiński M. [2011b], Szczegółowa metodyka audytu wewnętrznego [w:] Audyt wewnętrzny $w$ doskonaleniu instytucji, red. M. Lisiński, PWE, Warszawa.

Lisiński M. [2013], Structural Analysis of the Management Science Methodology, „Business, Management and Education”, vol. 11, nr 1, https://doi.org/10.3846/bme.2013.07.

Lisiński M. [2014], Metodologia apragmatyczna nauk o zarządzaniu, „Organizacja i Kierowanie", nr 1A (159).

Lisiński M. [2016a], Metodologia pragmatyczna nauk o zarządzaniu, „Zarządzanie i Finanse", nr 2, cz. 1.

Lisiński M. [2016b], Metody naukowe w metodologii nauk o zarządzaniu, „Przegląd Organizacji”, $\mathrm{nr} 4$.

Miller G. [1956], The Magical Number Seven, Plus or Minus Two: Some Limits on Our Capacity for Processing Information, „The Psychological Review”, vol. 63, nr 2, https://doi.org/10.1037/h0043158.

Mortimerowa H. [1987], Prawdopodobieństwo logiczne [w:] Filozofia a nauka. Zarys encyklopedyczny, red. Z. Cackowski, J. Kmita, K. Szaniawski, P.J. Smoczyński, Ossolineum, Wrocław.

Niemczyk J. [2011], Metodologia nauk o zarządzaniu [w:] Podstawy metodologii badań w naukach o zarzadzaniu, red. W. Czakon, Wolters Kluwer, Warszawa.

Nowak S. [2012], Metodologia badań społecznych, Wydawnictwo Naukowe PWN, Warszawa.

Pszczołowski T. [1978], Mała encyklopedia prakseologii i teorii organizacji, Ossolineum, Wrocław.

Stabryła A. [1986], Podstawy procesu zarządzania [w:] Organizacja i zarzadzanie. Zarys problematyki, red. A. Stabryła, J. Trzcieniecki, PWN, Warszawa.

Such J., Szcześniak M. [1999], Filozofia nauki, Wydawnictwo Naukowe Uniwersytetu A. Mickiewicza w Poznaniu, Poznań.

Sułkowski Ł. [2011], Struktura teorii naukowych w zarzadzaniu [w:] Podstawy metodologii badań w naukach o zarzadzaniu, red. W. Czakon, Wolters Kluwer, Warszawa.

Sułkowski Ł. [2012], Epistemologia i metodologia zarzadzania, PWE, Warszawa. 
Szarucki M. [2015], Evolution of Managerial Problems from the Perspective of Management Science, ,Business: Theory and Practice”, vol. 16, nr 4, https://doi.org/10.3846/ btp.2015.684.

Tatarkiewicz W. [2005], Historia filozofii. Filozofia XIX wieku i współczesna, t. 3, PWN, Warszawa.

Witczak H. [2012], Problemy i twierdzenia naukowe [w:] Podstawy metodologiczne prac doktorskich, red. M. Sławińska, H. Witczak, PWE, Warszawa.

Witczak H. [2014], Wstęp do naukowego statusu koncepcji zarzadzania, „Organizacja i Kierowanie", nr 2.

Ziembiński Z. [2009], Logika praktyczna, Wydawnictwo Naukowe PWN, Warszawa.

\section{Scientific Procedures of Complete and Incomplete Induction in the Methodology of Management Science}

\section{(Abstract)}

The article presents the characteristics of the two basic scientific procedures used in management science. The procedures for complete induction and incomplete induction are presented from the perspective of the general methodology of science, the philosophy of science and the achievements of the methodology of management science. The analysis of these procedures specifically focuses on methods and techniques as well as on methodological directives relating them to the distinguished phases within the procedures of scientific research.

Keywords: scientific procedures, methodology, management sciences, complete induction, incomplete induction. 